\title{
Taxonomic Diversity and Structure of Benthic Macroinvertebrates of Taabo Lake (Basin of Bandama; Ivory Coast)
}

\author{
Yanick Djoman Tanon ${ }^{1}$, Idrissa Adama Camara ${ }^{1}$, Norbert Kouakou Kouadio ${ }^{2}$, Lassina Doumbia ${ }^{1}$, Allassane \\ Ouattara $^{1} \&$ Dramane Diomandé ${ }^{1}$ \\ ${ }^{1}$ Université Nangui Abrogoua, UFR des Sciences et Gestions de l'Environnement, Côte d'Ivoire \\ ${ }^{2}$ Université de Man, UFR des Sciences de l'Ingénierie Agronomique Forestière et Environnementales, Côte \\ d'Ivoire \\ Correspondence: Yanick Djoman Tanon, Université Nangui Abrogoua, UFR des Sciences et Gestions de \\ l'Environnement, 02 BP 801 Abidjan 02, Côte d'Ivoire.
}

Received: January 24, 2020

Accepted: February 28, 2020

Online Published: April 12, 2020

doi:10.20849/jess.v3i1.734

URL: https://doi.org/10.20849/jess.v3i1.734

\begin{abstract}
The taxonomic diversity and structure of benthic macroinvertebrates of Taabo Lake (Ivory Coast), from November 2017 to October 2018 were evaluated. Water quality parameters, such as temperature $\left(\mathrm{T}{ }^{\circ} \mathrm{C}\right)$, water transparency $(\mathrm{cm})$, dissolved oxygen (mg.L-1), pH, turbidity (NTU), electrical conductivity (EC, $\mu$ S.cm-1) were measured in situ using a multi-parameter probe HANNA, from four sampling points (littoral and sub-littoral zones) in Taabo Lake. Benthic macroinvertebrates sampling were collected by using Van veen in stainless steel. A total of 63 benthic macroinvertebrates taxa belonging to 23 Families, 8 Orders, 2 Classes and 2 Phylums (Molluscs and Arthropods) were identified. The most abundant of benthic macroinvertebrates were Mesogastropoda (66\%) represented in all sampling points. They were followed by Diptera (25\%), Odonata (3\%), Ephemeroptera (3\%), Basommatophora (2\%), Heteroptera (1\%), Lepidoptera and Coleoptera (less than 1\%). The values of diversity indices of benthic macroinvertebrates collected in Taabo Lake showed no significant variations between sampling points.
\end{abstract}

Keywords: benthic macroinvertebrates, taxonomic diversity, structure, Taabo Lake, Ivory Coast

\section{Introduction}

The construction of dams and reservoirs for hydropower production and flood control, water abstraction for irrigation, along with other water uses, has changed the natural hydrologic regimes of freshwaters worldwide (Dynesius and Nilsson 1994). These environments transform lotic in lentic environments, causing reduction of water flow and more deposition of fine sediment, increase of deep and water transparency, modifying also the physical and chemical conditions and the structure of biological communities (Tundisi 1986; Palmer et al. 2000). Within the aquatic communities, benthic macroinvertebrates represent one of the groups most affected by reservoir construction (Krzyzanek 1991; Krzyzanek and Kasza 1995).

Benthic macroinvertebrates are vital to the functioning of lakes by recycling autochthonous and allochthonous carbon and nutrients (Karlsson and Byström 2005 ; Berggren et al. 2010) and constituting an important resource pool for several aquatic top predators (Vander Zanden and Vadeboncoeur 2002; Vander Zanden et al. 2006), besides being important intermediate hosts of several parasite species present in lake food webs (Amundsen et al. 2003). Benthic macroinvertebrate communities are the most commonly used organisms for the assessment and monitoring of the ecological status of lakes and reservoirs (Bailey et al. 2001). Furthermore, they often show the strongest responses among bioindicators to water drawdown (White et al. 2008; Sutela et al. 2013). Their composition and abundance in lakes and reservoirs typically vary considerably with water depth, with species richness generally being higher near the shore than in deep water (Strayer 2008; Ngupula and Kayanda 2010).

In Ivory Coast, there are several studies on reservoirs and dams (Ayamé 1 and 2, Kossou, Taabo, Buyo et Faé). These studies were concentrated on their physical, chemical, hydrology, and biological characteristics (Galy-Lacaux et al. 1999; Ouattara 2000; Yapo 2002; Kouamé et al. 2010; Kouamé et al. 2011). Among them, only the works of Kouamé et al. $(2010 ; 2011)$ have dealed about macroinvertebrate communities associated with macrophytes in the Taabo Lake. But, there are no studies investigating the benthic communities of 
macroinvertebrates of this Lake. The present study aimed at providing a first database on the benthic macroinvertebrates of the Taabo Lake.

Specificaly, this study aims: (1) to evaluate the composition and structure of benthic macroinvertebrates commnities of the Taabo Lake and (2) to determine the relationship between their assemblages and the main environmental variables in this lotic system.

\section{Material and Methods}

\subsection{Study Area}

Lake Taabo is a reservoir located between $6^{\circ} 19^{\prime}-6^{\circ} 40^{\prime} \mathrm{N}$ latitude and $5^{\circ} 07^{\prime}-5^{\circ} 26^{\prime} \mathrm{W}$ longitude on the Bandama River, approximately $110 \mathrm{~km}$ downstream of the confluence of the Bandama and Marahoué rivers (Figure 1). The Lake covers a surface area of $69 \mathrm{~km}^{2}$. The climate is tropical and humid with a mean annual temperature of $28.2^{\circ} \mathrm{C}$ (Sakho 1991). Four seasons occur in the Lake Taabo region: (1) a major dry season (December-March),

(2) a major rainy season (April-July), (3) a minor dry season (July-September) and (4) a minor rainy season (September-November) (Kouamé 2015).

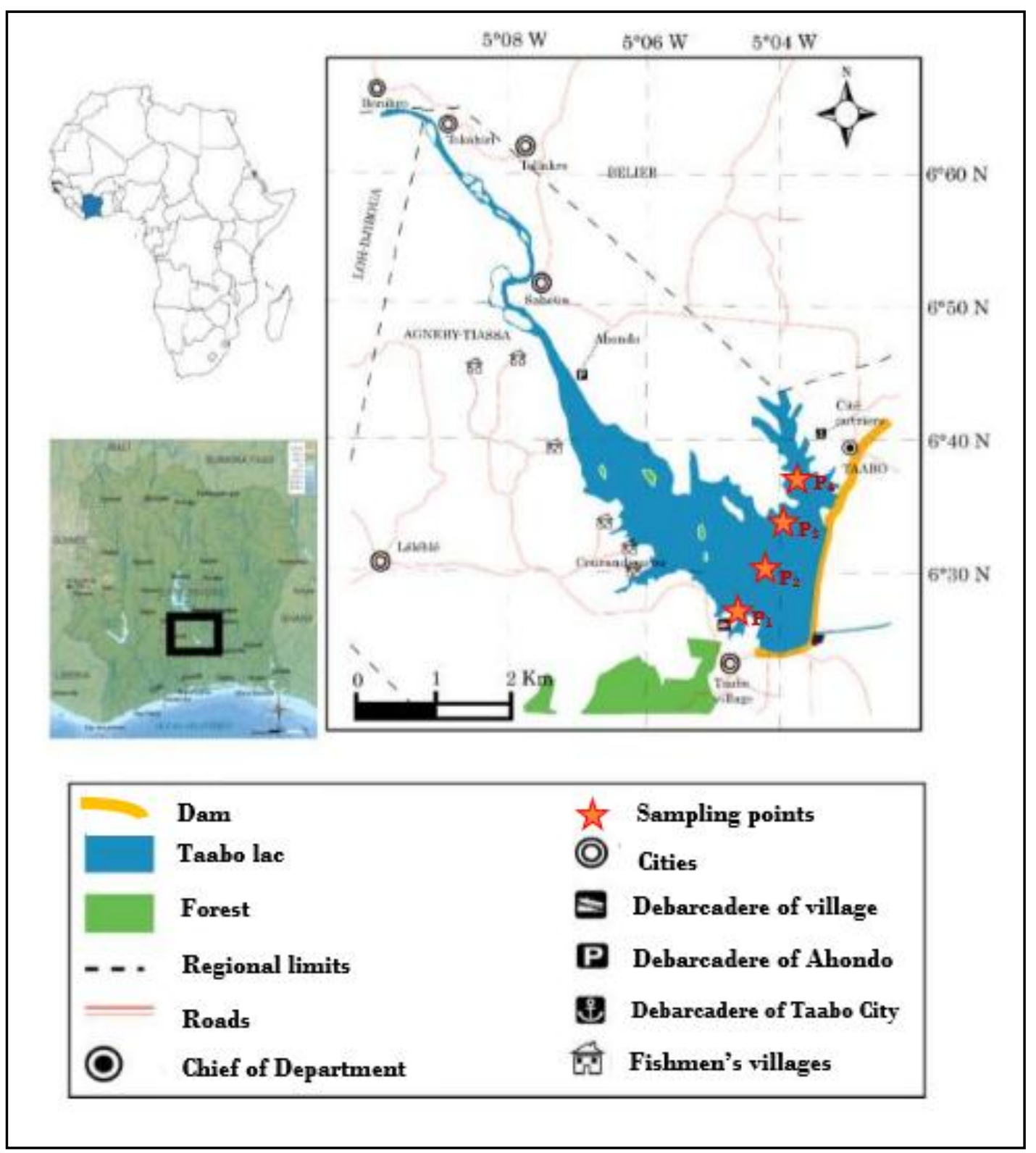

Figure 1. Map of the man-made Lake Taabo, showing sampling stations 


\subsection{Sampling of Benthic Macroinvertebrates}

The major community which Klugh (1923) referred to as the lake bottom association has commonly been divided by limnologists into the littoral, sublittoral and profundal zones. These zones are defined as follows: (1) littoral, from the lake margin to a depth at which aquatic vegetation, through lack of light, can no longer grow; (2) sublittoral, extends from the lower edge of the rooted macrophyte zone to about the level of the upper boundary of the hypolimnion; and (3) profundal, roughly, the area of the bottom in contact with the hypolimnion, which consists of exposed fine sediment free of vegetation (Williams and Feltmate, 1992).

During this study, benthic macroinvertebrates were collected in all the seasons of the year beginning in November 2017 to October, along one transect parallel to the dam. On this transect, four sampling points were chosen (P1 to P4). The sampling points P1 and P4, are located in the littoral zones. These stations are characterized by the presence of macrophytes and receive influence from the predominant human activities (washing and bathing). The predominant substrata are sand and gravels.

The last two sampling points P2 and P3, are located in the sub-littoral zones. The vegetal covering is absent and the predominant substrata is mud.

The characteristics of Taabo sampling stations are given in Table 1. Sampling was carried out in all the seasons of the year, beginning in November 2017 to October 2018.

Table 1. Characteristics of sampling points (P1-P4) in Taabo Lake

\begin{tabular}{lllll}
\hline Sampling points & Littoral 1 (P1) & Sub-littoral 1 (P2) & Sub-littoral 2 (P3) & Littoral 2 (P4) \\
\hline Coordinates & $06^{\circ} 15^{\prime} 46.6^{\prime} \mathrm{N}$ & $06^{\circ} 15^{\prime} 42.5^{\prime \prime} \mathrm{N}$ & $06^{\circ} 13^{\prime} 00.8^{\prime} \mathrm{N}$ & $06^{\circ} 12^{\prime} 59.2^{\prime \prime} \mathrm{N}$ \\
& $05^{\circ} 04^{\prime} 57.4^{\prime \prime} \mathrm{W}$ & $05^{\circ} 04^{\prime} 59.3{ }^{\prime} \mathrm{W}$ & $05^{\circ} 06^{\prime} 13.7^{\prime \prime} \mathrm{W}$ & $05^{\circ} 06^{\prime} 14.66^{\prime} \mathrm{W}$ \\
Bottom structure & Sand, gravel, stones & Vase & Vase & Sand, gravel \\
Aquatic vegetation & Yes & No & No & Yes \\
Water depth (m) & 1.6 & 6.3 & 8.9 & 2.7 \\
\hline
\end{tabular}

Littoral and sub-littoral (from dephts ranging 6-9 meters) samples were collected using Van Veen sampler in stainless steel. At each point, five sediment samples corresponding to a total area of $0.25 \mathrm{~m}^{2}$ were taken. All samples were sieved in situ through a $1 \mathrm{~mm}$ mesh. The organisms retained were packed in plastic bags, labelled, fixed immediately in $70 \%$ alcohol and transported to the laboratory for processing. In the laboratory, the collected material was washed on a mesh of $0.25 \mathrm{~mm}$, and sorted in Petri dishes, using stereomicroscope. The organisms were identified until the less possible taxonomic level, using identification keys of Diomandé et al. (2000), Tachet et al. (2010) And De Moor et al. (2003).

\subsection{Physical and Chemical Variables of Water}

Simultaneously with benthic macroinvertebrates sampling, the water temperature $\left(\mathrm{T}^{\circ} \mathrm{C}\right)$, electrical conductivity $\left(\mathrm{EC}, \mu \mathrm{S} . \mathrm{cm}^{-1}\right)$, hydrogen-ion concentration $\left(\mathrm{pH} ; \mathrm{pH}\right.$ unit), dissolved oxygen $\left(\mathrm{mg} . \mathrm{L}^{-1}\right.$ ) turbidity (NTU) were measured using multi-parameter probe HANNA HI 9146 and HANNA HI 99 1001. The transparency $(\mathrm{cm})$ was measured with a Secchi disc.

\subsection{Data Analyses}

The benthic macroinvertebrate composition and structure were evaluated using: rarefied taxonomic richness, relative abundance, diversity (Shannon-Wiener index), evenness (Pielou index) and density. The frequency of occurrence was determined for each taxa: rare $(<25 \%)$, frequent $(25-50 \%)$, and very frequent $(>50 \%)$ (Dajoz 2000). Before performing the comparison test, variations in environmental variables and biotic index were determined using Shapiro test. A significance level 0.05 was considered. This analysis was performed using the STATISTICA 7.1 computer package.

A Principal Focused Component Analysis (FPCA) was carried out using the R package (R Core Team 2013) to assess the main relationships between environmental variables and aquatic benthic macroinvertebrates. This analysis was computed with the Ade4 package (Chessel et al. 2004) for the R 3.0.2 freeware. 


\section{Results}

\subsection{Variations of Physicochemical Parameters of Taabo Lake}

The spatial variations of physicochemical water parameters are illustrated in Figure 2. Temperature had highest value $\left(35^{\circ} \mathrm{C}\right)$ in point $\mathrm{P} 1$ and lowest value $\left(26.5^{\circ} \mathrm{C}\right)$ in point $\mathrm{P} 4$. Concerning the $\mathrm{pH}$, its value ranged from 5.1 (P3) to 9.98 (P1). Conductivity had highest value $\left(110.5 \mu \mathrm{S} . \mathrm{cm}^{-1}\right)$ recorded at point $\mathrm{P} 3$ and lowest value $(60$ $\left.\mu \mathrm{S} . \mathrm{cm}^{-1}\right)$ at point $\mathrm{P} 2$.

The concentration of dissolved oxygen recorded the higher value $\left(8.5 \mathrm{mg} . \mathrm{L}^{-1}\right)$ at point $\mathrm{P} 3$, and lower value $(0.2$ $\left.\mathrm{mg} . \mathrm{L}^{-1}\right)$ at point $\mathrm{P} 2$. The higher value of turbidity (100 NTU) was observed at point P3 and the lowest value (20 $\mathrm{cm})$ was recorded at this point. Turbidity had lowest value $(5 \mathrm{NTU})$ at point P1, while the higher value of transparency $(100 \mathrm{~cm})$ was obtained at point P1. The values of abiotic variables of Taabo Lake showed no significant variations between sampling points (Mann-Whitney test; $p>0.05$ ).
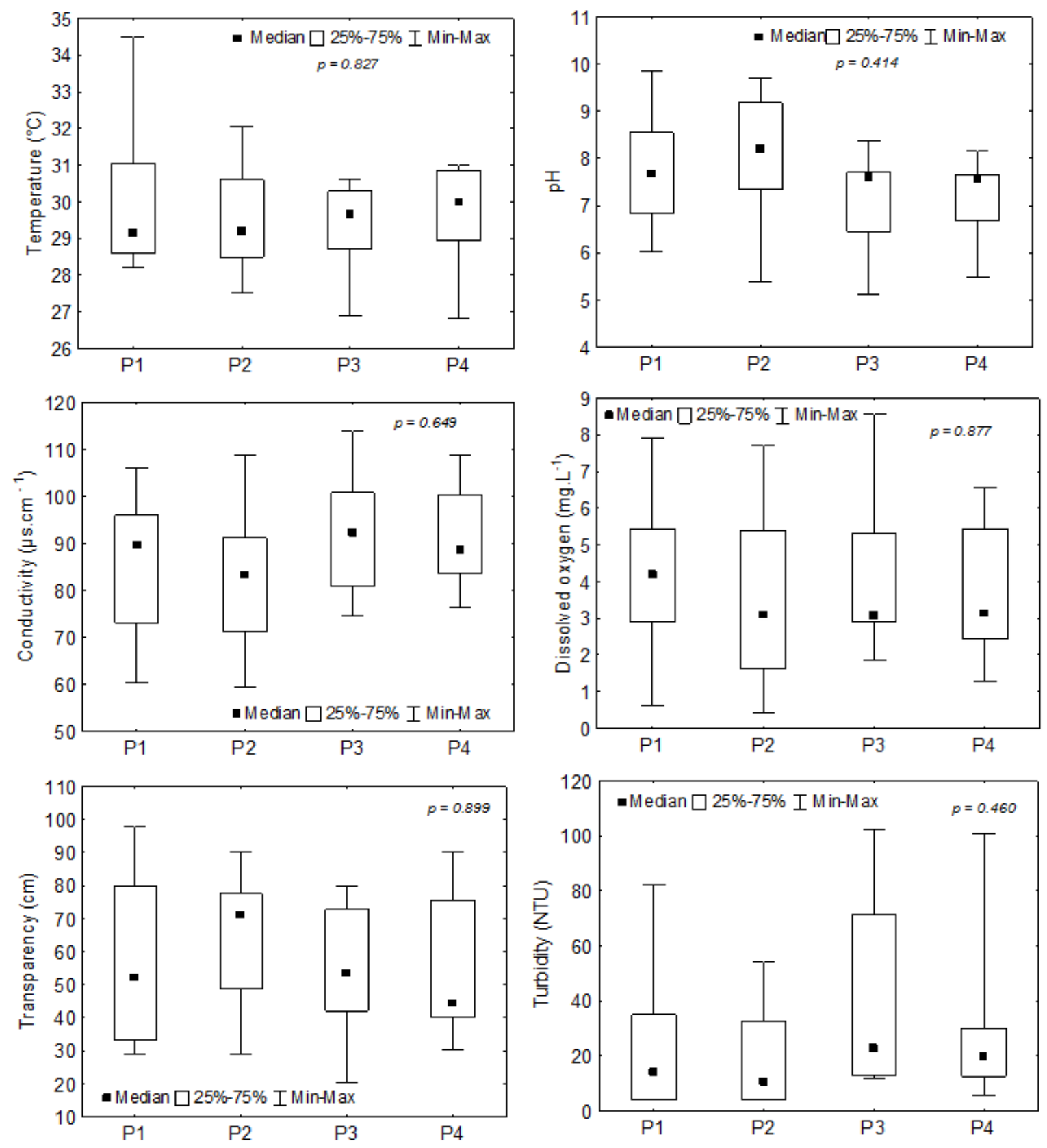

Figure 2. Spatial variations of environmental variables recorded in the sampling points of Taabo 


\subsection{Taxonomic Composition of Benthic Macroinvertebrates}

A total of 63 benthic macroinvertebrates taxa belonging to 23 Families, 8 Orders, 2 Classes and 2 Phylums (Molluscs and Arthropods) were identified during this study (Table 2). The phylum of Molluscs includes 14 taxa divided between 7 Families and 2 Orders (Basommatophora and Mesogastropoda) all belonging to the class of Gasteropods. In this class, the taxa Melanoides tubercula was found in all sampling points.

The Arthropods are represented by the class of Insects. This class includes 63 taxa belonging to 6 Orders (Ephemeroptera, Heteroptera, Coleoptera, Lepidoptera, Odonata and Diptera) and 16 Families. Among theses families, Chironomidae were the most diversified with 12 taxa.

The anlysis of the taxonomic richness showed that station $\mathrm{S} 1$ is the most diversified with (53 taxa), followed by point P4 (38 taxa), and point P3 (7 taxa). Point P2 (3 taxa) had the lowest taxonomic richness (Table 2)

Table 2. Taxonomic list of benthic macroinvertebrates registered in the sampling points of Taabo Lake and their occurrence

\begin{tabular}{|c|c|c|c|c|c|c|c|c|}
\hline \multirow[b]{2}{*}{ Phylum } & \multirow[b]{2}{*}{ Class } & \multirow[b]{2}{*}{ Order } & \multirow[b]{2}{*}{ Family } & \multirow[b]{2}{*}{ Taxa } & \multicolumn{4}{|c|}{ Sampling points } \\
\hline & & & & & P1 & $\mathbf{P 2}$ & $\mathbf{P 3}$ & $\mathbf{P 4}$ \\
\hline \multirow[t]{14}{*}{ MOLLUSCS } & Gasteropods & Basommatophora & Corbuliidae & Corbulla gibba & $*$ & & & \\
\hline & & & Lymneidae & Lymnea natalensis & $* *$ & & & $*$ \\
\hline & & & Planorbidae & Bulinus globosus & $* *$ & & & $* *$ \\
\hline & & & & Bulinus forskalii & $* *$ & & & \\
\hline & & & & Bulinus troncatus & $*$ & & & \\
\hline & & & & Biomphalaria pfeifferi & $* *$ & & & $* *$ \\
\hline & & & & Indoplanorbis exustus & $*$ & & & \\
\hline & & Mesogastropoda & Ampullariidae & Lanites varicus & $* *$ & & & $*$ \\
\hline & & & & Pila africana & $* * *$ & & $*$ & $* * *$ \\
\hline & & & Bythiniidae & Gabiella africana & $* * *$ & $* *$ & & $*$ \\
\hline & & & Thiaridae & Melanoides tuberculata & $* * *$ & $* * *$ & $*$ & $* * *$ \\
\hline & & & & Melanoides sp. & $*$ & & & \\
\hline & & & Melaniidae & Pachymelania fusca & & $*$ & & \\
\hline & & & Pomatiopsidae & Tomichia sp. & $*$ & & $*$ & \\
\hline \multirow[t]{11}{*}{ ARTHROPODS } & Insects & Ephemeroptera & Baetidae & Afrobaetodes sp. & $* *$ & & & $*$ \\
\hline & & & & Baetis sp. & $* *$ & & & $* *$ \\
\hline & & & & Cleon sp. & $*$ & & & $* *$ \\
\hline & & & & Pseudocleon sp. & $*$ & & & $* *$ \\
\hline & & & Caenidae & Caenis sp. & $*$ & & & \\
\hline & & Ephemeroptera & Leptophlebiidae & Adenophlebiodes sp. & & & & $* *$ \\
\hline & & & & Thraulus sp. & $*$ & & & $* *$ \\
\hline & & Heteroptera & Belostomatidae & Diplonychus sp. & $* *$ & & & $* *$ \\
\hline & & & & Limnogeton sp. & $* *$ & & & \\
\hline & & & & Lethocerus sp. & $*$ & & & \\
\hline & & & Naucoridae & Laccocoris sp. & $*$ & & & $* *$ \\
\hline
\end{tabular}

Very frequent taxa $(\mathrm{FO}>50 \%)$; Frequent taxa $(25 \% \leq \mathrm{FO} \leq 50 \%)$; Rare taxa $(\mathrm{FO}<25 \%)$ 
Table 2. End

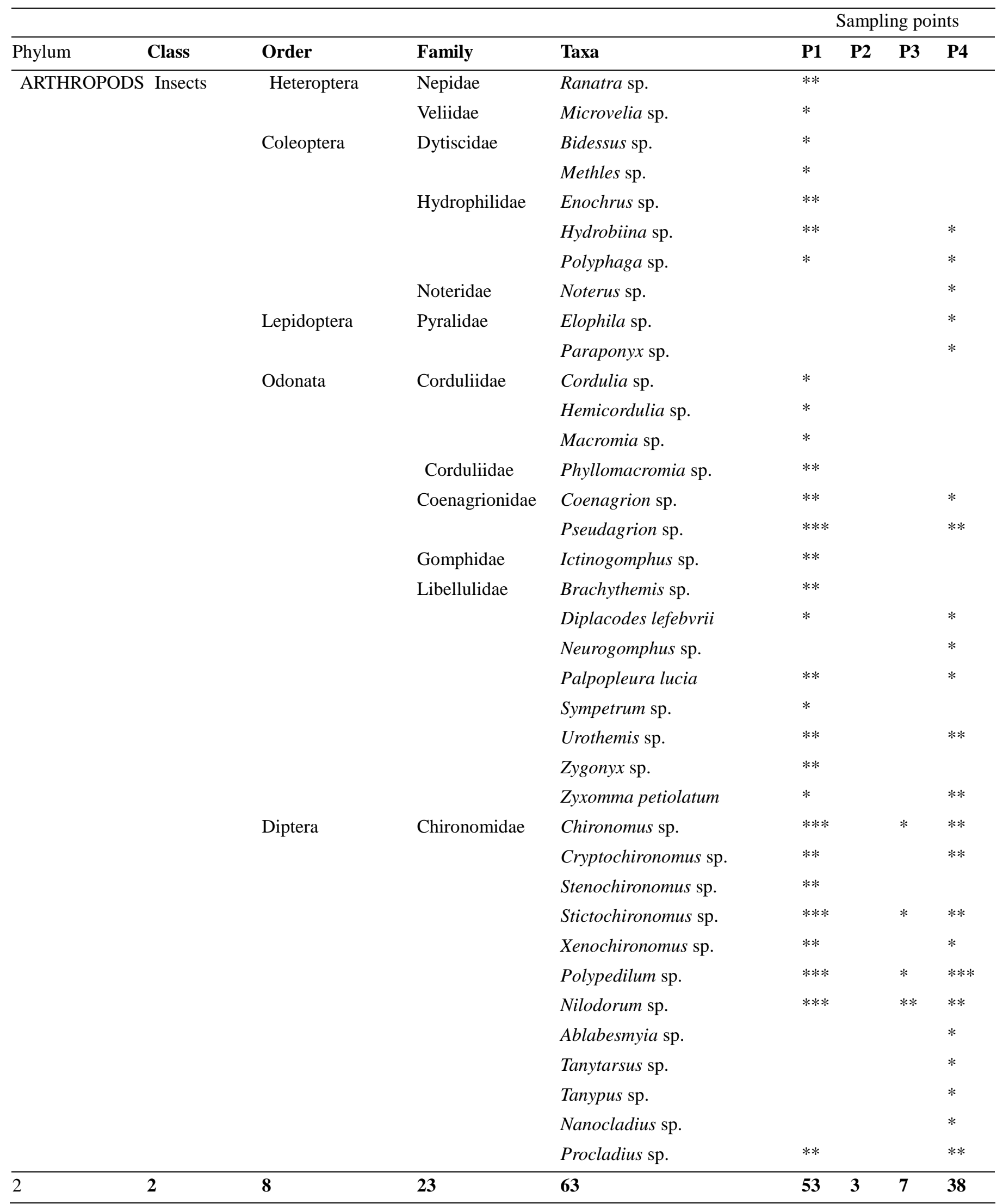

Very frequent taxa (FO > 50\%); Frequent taxa $(25 \% \leq \mathrm{FO} \leq 50 \%)$; Rare taxa $(\mathrm{FO}<25 \%)$ 


\subsection{Frequency of Occurrence}

Melanoides tuberculata (Thiaridae) is the only commonest taxa (FO > 50\%) found at all the sampling points ( $\mathrm{P} 1$ and P4) (Table 3). Pila africana (Ampullariidae), Gabiella africana (Bythinidae) and Polypedilum sp. (Chironomidae) were frequently $(25 \% \leq \mathrm{FO} \leq 50 \%)$ found in the majority of sampling points. In P1, 8 taxa were (Pila africana, Gabiella africana, Melanoides tuberculata, Pseudagrion sp., Chironomus sp., Stictochironomus sp., Polypedilum sp., Nilodorum sp.) were very frequent, and 22 were frequent. P2 registered 1 taxa very frequent (Melanoides tuberculata), 1 taxa frequent (Pila africana) and 1 taxa rare (Pachymelania fusca). In P4 registered 3 taxa were very frequent (Pila africana, Melanoides tuberculata, Polypedilum sp.) and 17 frequent taxa.

\subsection{Structure and Distribution of Benthic Macroinvertebrates}

The global abundance of the benthic macroinvertebrates collected from each sampling point are shown in Figure 3. The most abundant of benthic macroinvertebrates were Mesogastropoda (66\%) represented in all sampling points. They were followed by Diptera (25\%), Odonata (3\%), Ephemeroptera (3\%), Basommatophora (2\%), Heteroptera (1\%), Lepidoptera and Coleoptera (less than 1\%) (Figure 3). Concerning the spatial abundance, the sampling points P1 and P4 located in littoral zones were dominated by Insects belonged to Diptera order, while the point P2 was characterized by a high abundance of Molluscs Gasteropods (Figure 4A).

The density of Gastropoda ranged from 96 individuals $/ \mathrm{m}^{2}$ (P3) to 1400 individuals $/ \mathrm{m}^{2}$ (P1). The highest density of Insects (Ind. $\left./ \mathrm{m}^{2}\right)$ was obtained at P1 and the lowest $\left(0\right.$ ind. $\left./ \mathrm{m}^{2}\right)$ were recorded at P2 (Figure 4B).

The Shannon index respectively reached high and low values at P1 (2.340) and P3 (than less 1). As the rarefied taxonomic richness, the highest value was obtained at P1 (2.580) and lowest at P2 (less than 1). Concerning the Equitability index, the highest value (2.580) were recorded at P1 and the lowet (less than 1) were obtained at P2. The values of diversity indices of benthic macroinvertebrates collected in Taabo Lake showed no significant variations between sampling points (Kruskal-Wallis test; $p>0.05$ ). (Table 3 ).

Table 3. Spatial variations in diversity indices of benthic macroinvertebrates registered in the sampling points of Taabo Lake

\begin{tabular}{|c|c|c|c|c|}
\hline \multicolumn{2}{|c|}{ Sampling points } & \multirow{2}{*}{$\begin{array}{c}\text { Shannon index } \\
0,381\end{array}$} & \multirow{2}{*}{$\begin{array}{c}\text { Rarefied richness } \\
1,200\end{array}$} & \multirow{2}{*}{$\begin{array}{c}\text { Equitability index } \\
0,166\end{array}$} \\
\hline & Min & & & \\
\hline P1 & Max & 2,340 & 2,580 & 0,727 \\
\hline & Median & 1,390 & 1,923 & 0,522 \\
\hline \multirow{3}{*}{$\mathrm{P} 2$} & Min & 0 & 1 & 0,067 \\
\hline & Max & 0,294 & 1,240 & 0,424 \\
\hline & Median & 0 & 1 & 0,245 \\
\hline \multirow{3}{*}{$\mathrm{P} 3$} & Min & 0 & 1 & 0 \\
\hline & Max & 0 & 1 & 0 \\
\hline & Median & 0 & 1 & - \\
\hline \multirow{3}{*}{ P4 } & Min & 1,177 & 1,953 & 0,661 \\
\hline & Max & 2,177 & 2,501 & 1,310 \\
\hline & Median & 1,631 & 2,434 & 0,769 \\
\hline \multicolumn{2}{|c|}{$\begin{array}{r}\text { Kruskal-Wallis test } \\
(p \text {-value })\end{array}$} & 0,082 & 0,053 & 0,018 \\
\hline
\end{tabular}




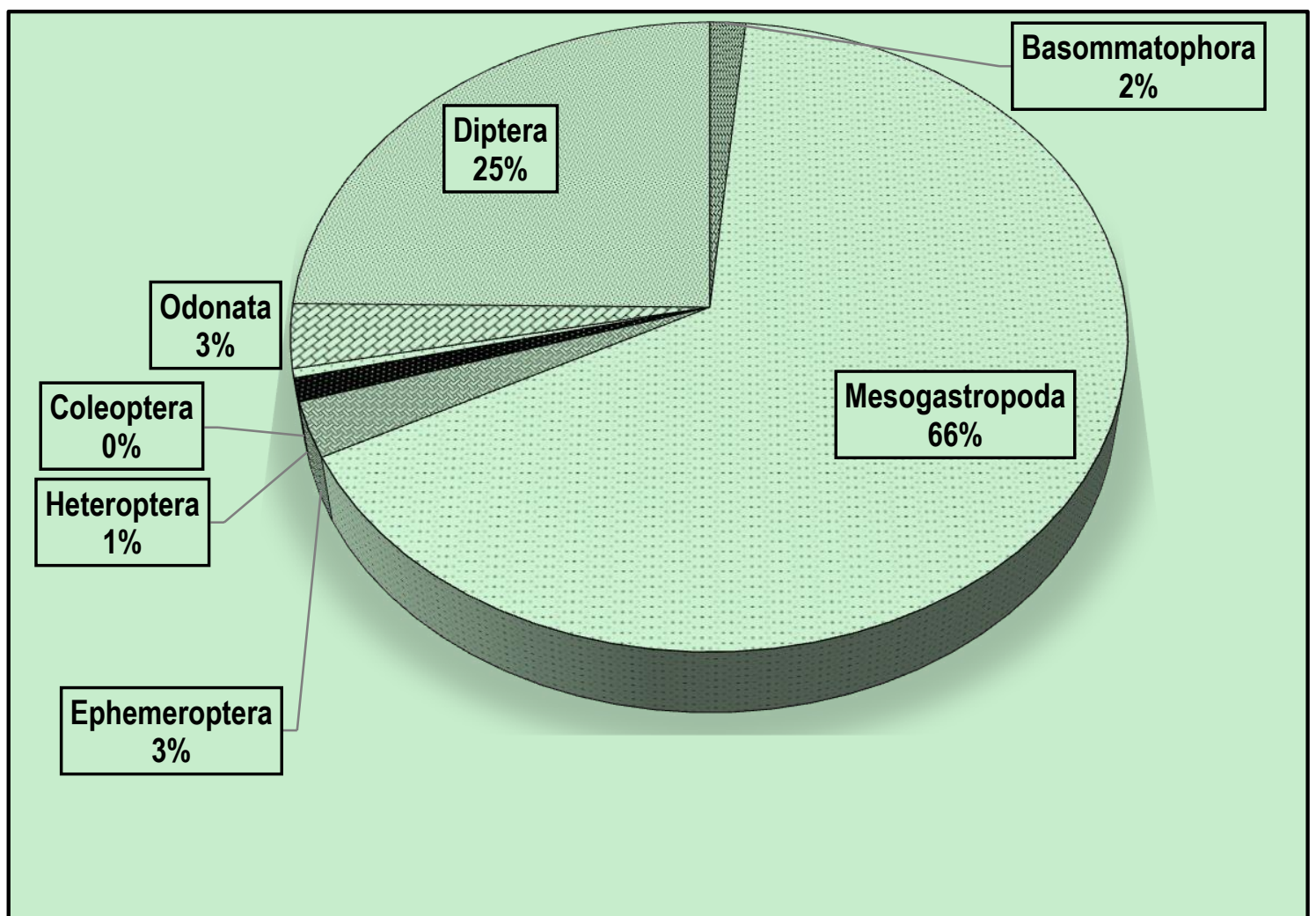

Figure 3. Global abundance of benthic macroinvertebrates orders collected in the sampling points of Taabo Lake (Ivory Coast) 

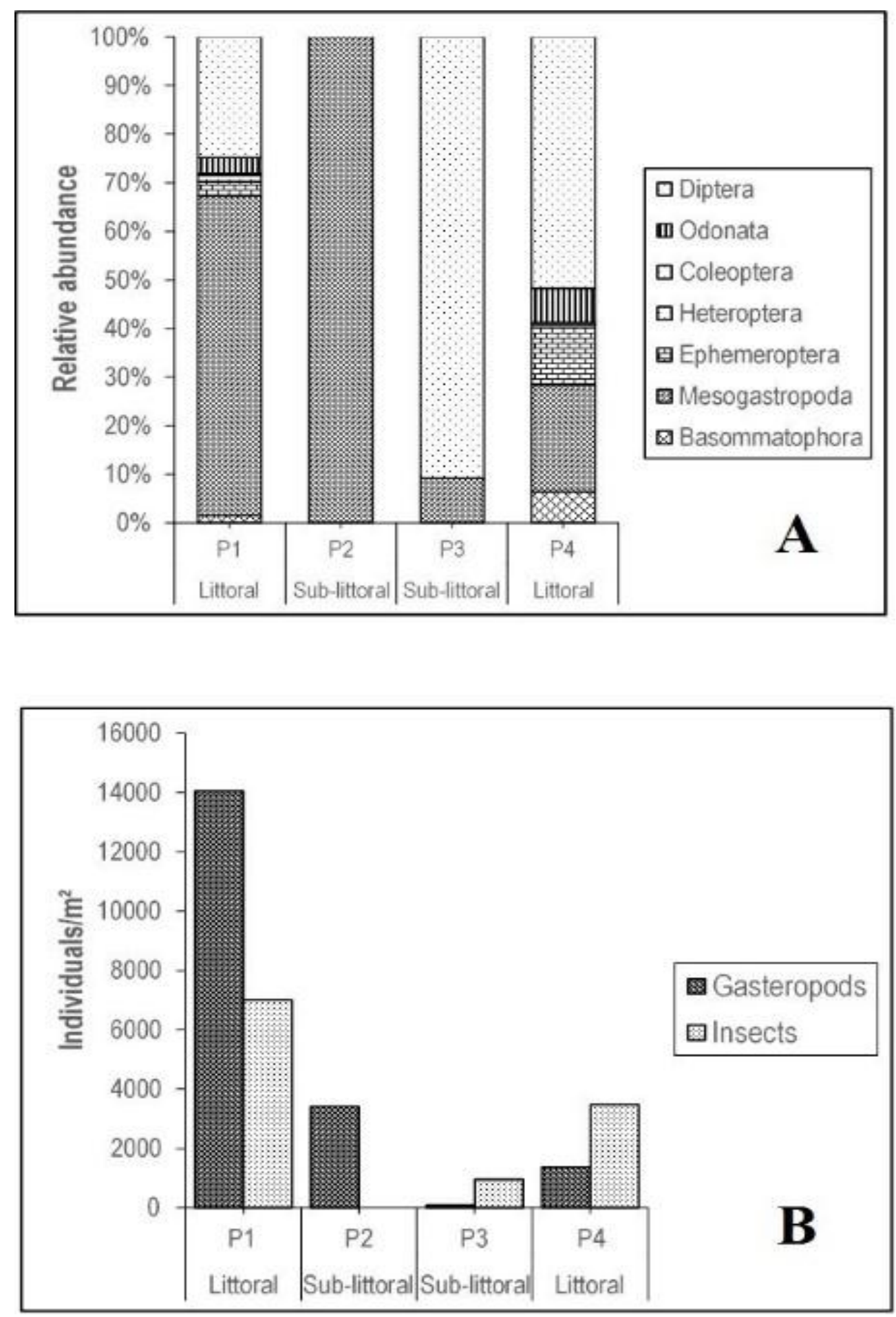

Figure 4. Assemblage structures of benthic macroinvertebrates orders collected in the sampling points of Taabo Lake. $(\mathrm{A})=$ Spatial variations $;(\mathrm{B})=$ Densities of Gasteropods and Insects

\subsection{Influence of Environmental Variables on Benthic Macroinvertebrates Community}

Principal Focused Component Analysis (FPCA) was performed using environmental variables with a focus on the most abundant taxa: Melanoides tuberculata (Mela), Lanites varicus (Lani), Baetis sp (Baet), Chironomus sp. (Chir), Cryptochironomus sp. (Cryp)., Nilodorum sp. (Nilo). and Polypedilum sp. (Poly). (greater than 10\% of 
global abundance). Thus, the FPCA relating to benthic macroinvertebrate taxa, reveals that the taxa Lanites varicus and Cryptochironomus sp. are significantly influenced $(p<0.05)$ by water depth. In addition, these taxa are negatively correlated with water depht (Figure 5).

The Diptera Chironomidae Chironomus imicola and Polypedilum sp. are positively correlated with conductivity. The taxon Baetis sp. belonging to the order Ephemeroptera, is positively correlated with conductivity. This insect is negatively correlated with water transparency.
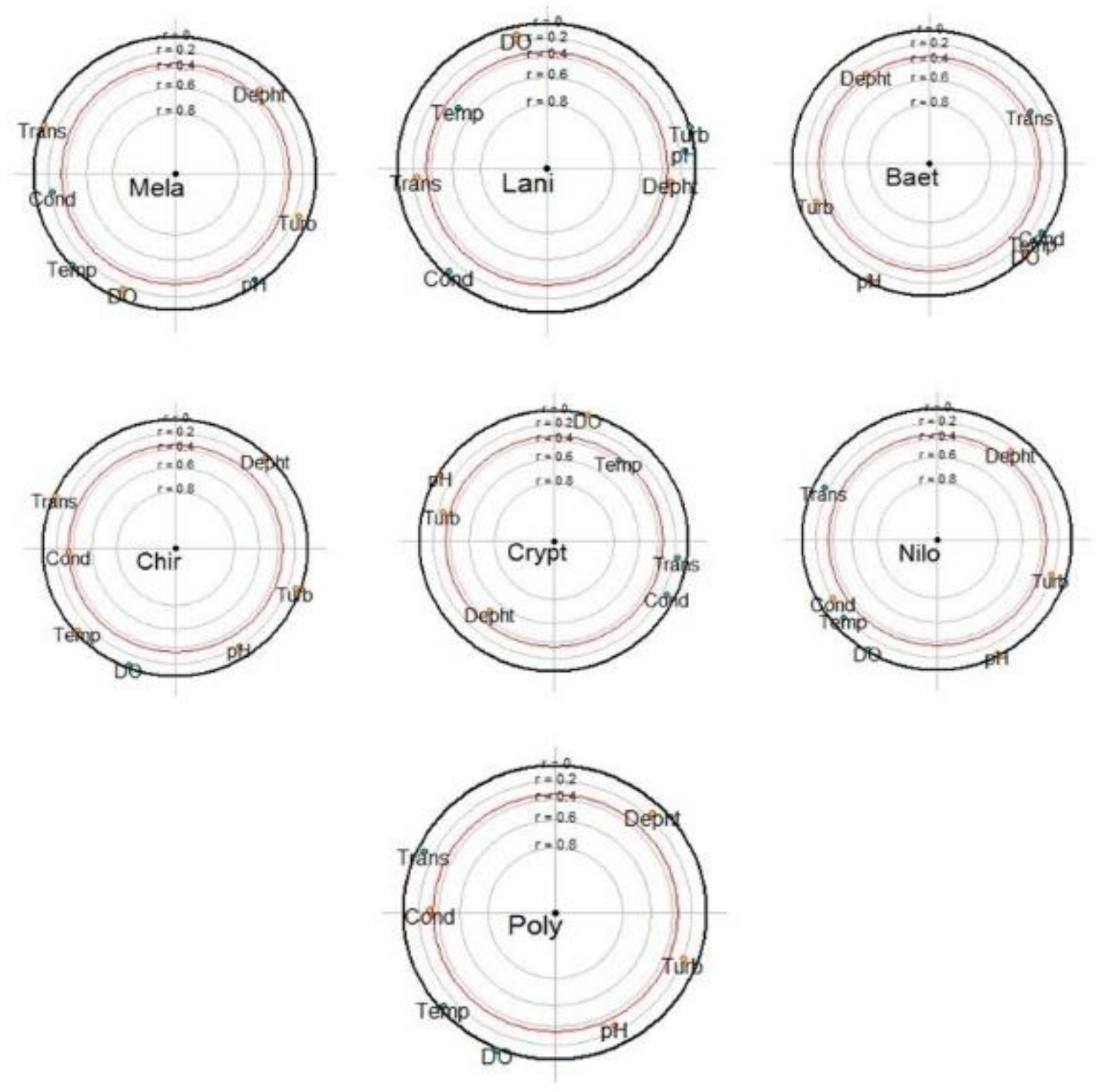

Figure 5. Graphs illustrating the results of Principal Focused Component Analysis (FPCA) based on the most abundant taxa of the Taabo Lake benthic macroinvertebrates as dependent variables and the abiotic parameters representing the independent variables. The yellow dots correspond to the abiotic parameters negatively correlated to the abundance of the taxon while the green dots indicate those which are positively correlated with the abundance of the taxon. The points inside the red circle represent the parameters significantly $(p<0.05)$ correlated with taxon abundance (Mela $=$ Melanoides tuberculata Lani $=$ Lanites varicus; Baet $=$ Baetis sp., Crypt $=$ Cryptochironomus sp. Chir = Chironomus sp.; Nilo = Nilodorum sp.; Poly $=$ Polypedilum sp. Temp = Water temperature; $\mathrm{OD}=$ Dissolved Oxygen; Cond = Conductivity; $\mathrm{pH}=$ Hydrogen Potential; Turb= Turbidity; Dept = Water depht). 


\section{Discussion}

Analysis of the physical and chemical parameters of Taabo Lake revealed that the abiotic parameters (temperature, hydrogen potential, dissolved oxygen, transparency, conductivity) shown no significant variation among sampling points. However, the high values of turbidity would be linked to effluents resulting from numerous human activities, namely the intensification of farming, washing and fisheries. Similarly, high values of conductivity are an indirect measure of the concentration of pollutants. Since conductivity is a numerical expression of the capacity of water to conduct electric current, thus depending on the ionic concentrations and temperature it indicates the amount of existing salts in the water column (Wetzel 1993). Detergents, which probably also come from sewage have phosphorus in their composition, which in excess leads to water eutrophication (Valente et al. 1997).

The settlement of collected benthic macroinvertebrates includes 63 taxa divided into 23 families, 8 orders and 2 classes. Taabo Lake taxonomic richness obtained was lower than that obtained by Kouamé et al. $(2010 ; 2011)$ in the same Lake. In terms of diversity, these authors found 68 and 43 taxa of macroinvertebrates respectively. They worked on the macroinvertebrates associated to macrophyte habitats. Their results showed the importance of macrophyte habitats on macroinvertebrates taxonomic diversity. Generally, the more diversified substrates provided by macrophytes contain more ecological niches than homogeneous systems, which can allow more species to coexist. Macrophyte beds also offer refuges against predation by fish and other macroinvertebrates (Padial et al. 2009).

In addition, macrophytes provide more surface area for attachment by periphytons, which are a major component in the diet of macroinvertebrate primary consumers. According Cai et al. (2010), macrophytes provide more surface area for attachment by periphytons, which are a major component in the diet of macroinvertebrate primary consumers. Thiaridae (Melanoides tuberculata) were the most dominant and abundant Mollusca across all the sampling points. This family (Thiaridae) dominance may be attributed to the competitive advantage they have over the other snails of rapidly increasing their populations (Kouamé et al. 1989).

In this study, Insecta represent the most diversified class with 49 taxa. The insects colonize all the aquatic environments owing to their dispersal capacity with with strong preference for freshwaters (Tachet et al. 2003). Insecta is dominated by Chironomidae family (Chironomus sp., Polypedilum sp.). Lentic waters tend to promote the reproduction of algae and zooplankton and thus the Chironomid finds enough food for their energy needs (Ouattara et al. 2001 ; Diomandé et al. 2013), and sot they can become very abundant organisms for tolerating large climate, hydrological and limnological variations (Pamplin et al. 2006 ; Jorcin and Nogueira 2008). According to Helson et al. (2006) and Vander Vorste (2010), Chironomidae larvae are both taxonomically and functionally diverse in aquatic systems, represent most feeding and habit guilds, and have a wide range of tolerance values to varying environmental conditions. Anderson et al. (2012) argue that Chironomidae larvae are known to thrive in polluted environment probably due to possession of hemoglobin a pigment that transport and store dissolved oxygen. The presence of these indicator species suggests organic pollution from anthropogenic source.

The high densities (individuals. $\mathrm{m}^{-2}$ ) at $\mathrm{S} 1$ and $\mathrm{S} 4$ (littoral zones) let us suppose that these stations are characterized by an important development of algae. According to Salmoiraghi et al. (2001), for most lakes and reservoirs, both the abundance and the number of benthic taxa are highest in the littoral zone and decreases as the depth increase.

Regarding the principal focused component analysis (FPCA) showing the influence of environmental factors on the benthic macroinvertebrates, only temperature, conductivity and water depth are the abiotic parameters which explain macroinvertebrates distribution along Taabo Lake. This situation could attributed to water fluctuations in lakes and reservoirs. Water-level fluctuations are more frequent in lakes in regions where raine vents are strongly seasonal and occur in an irregular precipitation regime (Geraldes and Boavida, 2005). According Mc Ewen and Butler (2010), such fluctuations may often cause spatial and temporal differences in water chemistry, which in turn, can affect the diversity, density and overall resilience of reservoir biota.

\section{Conclusion}

A total of seventy-height (63) taxa were recorded in the Taabo Lake in this study. Our study up to date the benthic macroinvertebrate of this ecosystem and showed that the Taabo Lake's benthic macroinvertebrate was composed mainly by taxa commonly found in tropical ecosystems. Benthic macroinvertebrate community is marked by the numerical dominance of Gastropoda (63\% of total abundance) and by the qualitative dominance of insect (37\% of the total taxa). Distribution of aquatic macroinvertebrates of the Taabo Lake was best explained by Temperature, conductivity, dissolved oxygen, transparency, nitrates, and $\mathrm{pH}$. The different indices 
studied, revealed that the ecological state is less alarming. It is therefore necessary to protect this.

\section{Recommendations}

For a better characterization of the entomological population, the dominant zoological group of macroinvertebrates from the Taabo reservoir, a deepening of their system is necessary, particularly for the family of Chironomidae. In addition, work should be carried out for a thorough knowledge of the diet of insects in the lake of the Taabo dam.

\section{Acknowledgements}

This research was funded by the Executive Management of Fisheries and Aquaculture (Ivory Coast). The authors are grateful to Prof. OUATTARA Allassane and DOUMBIA Lassian of the Department of Hydrobiology at the University of NANGUI ABROGOUA, Abidjan, Côte d'Ivoire, who were Project Managers.

\section{References}

Aggrey-Fynn, J., Galyuon, I., Aheto, D. W., \& Okyere, I. (2011). Assessment of environmental conditions and benthic macroinvertebrate communities in two coastal lagoons in Ghana. Annals of Biological Research 2(5), 413-424.

Aiwerioghene, O. A. N., \& Abeke Ayoade, A. A. (2006). Evaluation of some Physicochemical Parameters and Benthic Macroinvertebrates of Ikere Gorge Reservoir in Oyo State, Nigeria. Journal of Applied Science Environmental Management, 20(4), 1097-1103.

Amundsen, P. A., Knudsen, R., Kuris, A. M., \& Kristoffersen, R. (2003). Seasonal and ontogenetic dynamics in trophic transmission of parasites. Oikos, 102, 285-293.

Anderson, T. J., Stelzer, R. S., Drecktrah, H. G., \& Eggert, S. L. (2012). Secondary production of Chironomidae in a large eutrophic lake: implications for lake sturgeon production. Freshwater Science, 31, 365-378.

Bailey, R. C., Norris, R. H., \& Reynoldson, T. B. (2001). Taxonomic resolution of benthic macroinvertbrate communities in bioassessments. J. N. Am Benthological Soc., 20, 280-286.

Benetti, C. J., Perez-Bilbao, A., \& Garrido, J. (2012). Water Quality in running waters: 10 years of research in rivers with different degrees of anthropogenic impacts. Ecological Water Quality, 5, 95-122.

Berggren, M., Ström, L., \& Laudon, H. (2010). Lake secondary production fueled by rapid transfer of low molecular weight organic carbon from terrestrial sources to aquatic consumers. Ecol. Lett., 13, 870-880.

Birk, S., Bonne, W., Borja, A., Brucet, S., Courrat, A., Poikane, S., ... Hering, D. (2012). Three hundred ways to assess Europe's surface water: an almost complete overview the biological methods to implement the Water Framwork Directive. Ecological Indicators, 18, 31-41.

Bonada, N., Prat, N., Resh, V. H., \& Statzner, B. (2006). Developments in aquatic insect biomonitoring : a comparative analysis of recent approaches. Annual Review of Entomology, 51, 495-523.

Cai, Y., Gong, Z., \& Qin, B. (2010). Influences of habitat type and environmental variables on benthic macroinvertebrate communities in a large shallow subtropical lake (Lake Taihu, China). International Journal of Limnology, 47, 85-95.

Camara, I. A., Diomandé, D., Bony, Y. K., Ouattara, A., Franquet, E., \& Gourène, G. (2012). Diversity assessment of benthic macroinvertebrate communities in Banco National Park (Banco Stream, Côte d'Ivoire). African Journal of Ecology, 50, 205-217.

Campbell, N. (2002). Biologie (2 ed.). De Boeck, Bruxelles, p. 1364.

Covich, A. P., Palmer, M., \& Crowl, T. A. (1999). The role of benthic invertebrate species in freshwater ecosystems. Zoobenthic species influence energy flows and nutrient cycling. Bioscience, 49, 119-127.

De Moor, I. J., Day, J. A., \& De Moor, F. C. (2003). Guide to the freshwater Invertebrates of Southern Africa. Volume 7: Insecta I: Ephemeroptera, Odonata and Plecoptera. Rapport $N^{\circ}$ II 207/03. Water Research Commission, South Africa, p.228.

Diomandé, D., Gourène, G., Sankaré, Y., \& Zabi, S. G. (2000). Synopsis de la classification des larves et des nymphes de Diptères Chironomidae des écosystèmes dulçaquicoles de l'Afrique de l'Ouest. Clés de déterminations des sous-familles, des tribus et des genres. CRO, Abidjan. Archives Scientifiques, 17(1), $1-31$.

Diomandé, D., Kpai, N. N., Kouadio, K. N., Da Costa, K. S., \& Gourène, G. (2013). Spatial distribution and 
structure of benthic macroinvertebrates in an artificial reservoir: Taabo Lake (Côte d'Ivoire). International Journal of Biological and Chemical Sciences, 7(1), 503-514.

Dynesius, M., \& Nilsson, C. (1994). Fragmentation and flow regulation of river systems in the northern third of the World. Science, 266, 753-762.

Galy-Lacaux, C., Delmas, R., Kouadio, G., Richard, S., \& Gosse, P. (1999). Long-terme greenhouse gas emissions from hydroelectric reservoirs in tropical forest regions. Global Biogeochemical Cycle, 13, 503-517.

Geraldes, A. M., \& Boavida, M. J. (2005). Seasonal water level fluctuations: implications for reservoir limnology and management. Lakes reservoirs. Research of Management, 10, 59-69.

Helson, J., Williams, D., \& Turner, D. (2006). Larval chironomid community organization in four tropical rivers: human impacts and longitudinal zonation. Hydrobiologia, 559, 413-431.

Jorcin, A., \& Nogueira, M. G. (2008). Benthic macroinvertebrates in the Paranapanema reservoir cascade (southeast Brazil). Brazilian Journal of Biology, 68(4), 1013-1024.

Karlsson, J., \& Byström, P. (2005). Littoral energy mobilization dominates energy supply for top consumers in subarctic lakes. Limnololgy of Oceanography, 50, 538-543.

Klugh, A. B. (1923). A common system of classification in plant and animal ecology. Ecology, 4, 366-377.

Kouamé, K. M. (2014). Diversité, structure et réponse fonctionnelle des macroinvertébrés à l'invasion du lac de Taabo (Côte d'Ivoire) par la jacinthe d'eau, Eichhornia crassipes (Mart.) SolmsLaubach, 1883. Thèse de Doctorat, Université Nangui Abrogoua, Côte d'Ivoire, p.161.

Kouamé, K. M., Diétoa, Y. M., Édia, O. É., Da Costa, S. K., Ouattara, A., \& Gourène, G. (2010) Aquatic macroinvertebrate assemblages associated with root masses of water hyacinths, Eichhornia crassipes (Mart.) Solms-Laubach, 1883 (Commelinales: Pontederiaceae) in Taabo Lake, Ivory Coast. Journal of Natural History, 44(5-8), 257-278.

Kouamé, K. M., Diétoa, Y. M., Édia, O. É., Da Costa, S. K., Ouattara, A., \& Gourène, G. (2011). Macroinvertebrate communities associated with macrophyte habitats in a tropical man-made lake (Lake Taabo, Côte d'Ivoire). Knowledge and Management of Aquatic Ecosystems, 400(03), 1-18.

Krzyzanek, E. (1991). The formation of bottom macrofauna communities in three dam reservoirs in Silesia (southern Poland) from the beginning of their existence. Acta Hydrobiologia, 33(3/4), 265-305.

Krzyzanek, E., \& Kasza, H. (1995) Formation of bottom macrofauna in Goczałkowice reservoir (southern Poland) against the background of changing selected physico-chemical properties of the water. Krakow. Acta Hydrobiologia, 37(2), 103-111.

Mc Ewen, D. C., \& Butler, M. G. (2010). The effects of water-level manipulation on the benthic invertebrates of a managed reservoir. Freshwater Biology, 55, 1086-1101.

Ngupula, G. W., \& Kayanda, R. (2010). Benthic macrofauna community composition abundance and distribution in the Tanzanian and Uganda inshore and offshore waters of Lake Victoria. African Journal of Aquatic Science, 35, 185-192.

Ouattara, A., Podoor, N., \& Gourène, G. (2001). Études préliminaires de la distribution spatiotemporelle du phytoplancton d'un système lacustre africain (Bassin Bia, Côte d'Ivoire). Hydroécologie Appliquée, 13(1), 113-132.

Padial, A. A., Thomaz, S. M., \& Agostinho, A. A. (2009). Effects of structural heterogeneity provided by the floating macrophyte Eichhornia azurea on the predation efficiency and habitat use of the small Neotropical fish Moenkhausia sanctaefilomenae. Hydrobiologia, 624, 161-170.

Palmer, T. D., Willhoite, A. R., \& Gage, F. H. (2000). Vascular niche for adult hippocampal neurogenesis. The Journal of Comparative Neurology, 425(4), 479-494.

Pamplin, P. A. Z., Almeida, T. C. M., \& Rocha, O. (2006). Composition and distribution of benthic macroinvertebrates in Amercian Reservoir, SP, Brazil. Acta Limnological Brasiliensia, 18(2), 121-132.

Sakho, M. A. (1991). Indice de l'instabilité des ressources en eau sur la gestion d'un système d'eau aménagé. Exemple du bassin versant du Sassandra en Côte d'Ivoire. Ph. D. Thesis, University of Montpellier II, France.

Strayer, D. L. (2009). Benthic invertebrate fauna: lakes and reservoirs. In Likens, G.E. (Ed.), Encyclopedia of 
Inland water (Vol. 2, pp. 191-204). Elsevier, Oxfors.

Sutela, T., Aroviita, J., \& Keto, A. (2013). Assessing ecological status of regulated lakes with littoral macrophytes macroinvertebrate and fish assemblages. Ecological Indicators, 24, 185-192.

Tachet, H., Bournaud, M., \& Richoux, P. (2003). Introduction à l'étude des macroinvertébrés des eaux douces, Paris, France, p.587.

Tundisi, J. G. (1986). Ambientes, Represas E Barragens. Ciência Hoje, 5(27), 48-54.

Valente, J. P. S., Padilha, P. M., \& Silva, A. M. M. (1997). Contribution of Botucatu - SP with nutrients (phosphorus and nitrogen) to the eutrophication of the Barra Bonita dam. Eclética Química, 22, 31-28.

Vander Vorste, R. W. (2010). Hydroperiod, physicochemistry and seasonal change of macroinvertebrate communities in intermittent prairie streams. Thesis, South Dakota State University, Brookings, SD

Vander Zanden, M. J., \& Vadeboncoeur, Y. (2002). Fishes as integrators of benthic and pelagic food webs in lakes. Ecology, 83, 2152-2161.

Vander Zanden, M. J., Chandra, S., \& Park, S. K. (2006). Efficiencies of benthic and pelagic trophic pathways in a subalpine lake. Canadian Journal of Fisheries and Aquatic Sciences, 63, 2608-2620.

Wetzel, R .G. (1993). Limnologia. Lisboa: Fundação Calouste Gugelheim. p.919.

White, M. S., Xenopoulos, M. A., Hogsden, K., Metcalfe, M. A., \& Dilon, P. J. (2008). Natural Lake level fluctuation and associated concordance with water quality and aquatic communities within small lakes of the Laurentian Great Lakes region. Hydrobiology, 613, 21-31.

Williams, D. D., \& Feltmate, B. W. (1992). Aquatic Insects. CAB International, xiii, 358.

\section{Copyrights}

Copyright for this article is retained by the author(s), with first publication rights granted to the journal.

This is an open-access article distributed under the terms and conditions of the Creative Commons Attribution license (http://creativecommons.org/licenses/by/4.0/). 